\title{
MI TÖRTÉNIK A SZÉDÜLŐ BETEGGEL A SÜRGÖSSÉGI OSZTÁLY ELHAGYÁSA UTÁN?
}

\author{
MAIHOUB Stefani ${ }^{1}$, MOLNÁR András' ${ }^{1}$ CSIKÓS András², KANIZSAI Péter², TAMÁS László1, \\ SZIRMAI Ágnes'
}

'Semmelweis Egyetem, Fül-Orr-Gégészeti és Fej-Nyaksebészeti Klinika, Budapest

${ }^{2}$ Semmelweis Egyetem, Sürgősségi Betegellátó Osztály, Budapest

Hungarian | https://doi.org/10.18071/isz.73.0241 | www.elitmed.hu

Bevezetés - A szédülés a fájidalom mellett az egyik leggyakoribb panasz, amellyel a beteg felkeresi az orvosi ellátást. A modern diagnosztika ellenére a szédülés okának diagnosztizálása napjainkban is nehéz feladat, számos buktatót rejt magában.

Célkitưzés - Kérdőíves felmérésünk célja annak vizsgálata, hogy mi történik a szédülést panaszoló beteggel a sürgősségi ellátást követően.

Kérdésfelvetés - A sürgősségi osztályon felállított diagnózis és a késóbbi kivizsgálás eredménye között mennyire volt összefüggés? Hogyan alakult a betegek életminősége az idő függvényében?

A vizsgálat módszere - A Semmelweis Egyetem Sürgősségi Betegellátó osztályán megielent 879, szédülést panaszoló beteghez juttattuk el kérdőívünket.

A vizsgálat alanyai - A kitöltött kérdőíveket 308 betegtól (110 férfi, 198 nö, átlagéletkor 61,8 = 12,31 SD) kaptuk vissza, ezeket elemzésnek vetettük alá.

Eredmények - A sürgősségi diagnózisok megoszlása a következőképpen alakult: centrális eredetü ( $n=71$ ), szédülékenység ( $n=64)$ és BPPV $(n=51)$ voltak a leggyakoribb diagnózisok. A végleges diagnózis tisztázásáig eltelt idő leggyakrabban napokat (28,8\%), illetve heteket $(24,2 \%)$ igényelt, kiemelendő azonban, hogy 24,02\%-ban végleges diagnózis sosem született. A sürgősségi és a végleges diagnózis között csupán 80 beteg esetén $(25,8 \%)$ volt egyezés, amelyet alátámaszt a kvalitatív statisztikai elemzés (Cohen-féle Kappa-teszt) eredménye ( $\kappa=0,560)$, moderált összefüggést indikálva.

\author{
WHAT HAPPENS TO VERTIGINOUS POPULATION \\ AFTER EMISSION FROM THE EMERGENCY \\ DEPARTMENT? \\ Maihoub S, MD; Molnár A, MD; Csikós A, MD; \\ Kanizsai P, MD; Tamás L, MD; Szirmai Á, MD \\ Ideggyogy Sz 2020;73(7-8):241-247.
}

Background - Dizziness is one of the most frequent complaints when a patient is searching for medical care and resolution. This can be a problematic presentation in the emergency department, both from a diagnostic and a management standpoint.

Purpose - The aim of our study is to clarify what happens to patients after leaving the emergency department.

Methods - 879 patients were examined at the Semmelweis University Emergency Department with vertigo and dizziness. We sent a questionnaire to these patients and we had 308 completed papers back (110 male, 198 female patients, mean age $61.8 \pm 12.31$ SD), which we further analyzed.

Results - Based on the emergency department diagnosis we had the following results: central vestibular lesion $(\mathrm{n}=$ $71)$, dizziness or giddiness $(n=64)$ and BPPV $(n=51)$ were among the most frequent diagnosis. Clarification of the final post-examination diagnosis took several days $(28.8 \%)$, and weeks (24.2\%). It was also noticed that $24.02 \%$ of this population never received a proper diagnosis. Among the population only 80 patients $(25.8 \%)$ got proper diagnosis of their complaints, which was supported by qualitative statistical analysis (Cohen Kappa test) result ( $\mathrm{K}=0.560)$.

Discussion - The correlation between our emergency department diagnosis and final diagnosis given to patients is low, a phenomenon that is also observable in other countries. Therefore, patient follow-up is an important issue, including the importance of neurotology and possibly neurological examination.

Levelező szerző (correspondent): Dr. SZIRMAI Ágnes, Semmelweis Egyetem, Fül-Orr-Gégészeti és

Fej-Nyaksebészeti Klinika; 1083 Budapest, Szigony u. 36. Telefon: 06-20-9517-226, fax: 06-1-333-3316, e-mail: szirmai.agnes@med.semmelweis-univ.hu

https://orcid.org/0000-0002-8421-6452

Érkezett: 2019. november 29. Elfogadva: 2020. február 24. 
Megbeszélés - A sürgősségi osztályon felállított diagnózis és a késóbbi kivizsgálás eredménye közötti korreláció alacsony, de az eredmények a nemzetközi irodalomban is hasonlónak mondhatók. Emiatt fontos a betegek követése beleértve az otoneurológiai, illetve esetlegesen neurológiai kivizsgálás fontosságát.

Következtetések - A szédüléssel jelentkező betegek sürgősségi diagnosztikája nagy kihívás. A pontos anamnézis és a gyors, célzott vizsgálat a nehézségek ellenére tisztázhatja a szédülés centrális vagy perifériás eredetét.

Kulcsszavak: szédülés, sürgősségi ellátás, kérdőíves utánkövetés
Conclusion - Emergency diagnosis of vertigo is a great challenge, but despite of difficulties the targeted and quick case history and exact examination can evaluate the central or peripheral cause of the balance disorder. Therefore, to prevent declination of the quality of life the importance of further investigation is high.

Keywords: vertigo, emergency care, follow-up questionnaire
A szédülés a különböző lokalizációjú fájdalmak mellett az egyik leggyakoribb, sokszor ijesztő panasz, ami a beteget az orvoshoz viszi, illetve amivel a betegek a sürgősségi osztályon jelentkeznek ${ }^{1}$. Hazánkban nem áll rendelkezésre pontos, hivatkozható epidemiológiai adat a szédülésre vonatkozóan, mindazonáltal a szédülés a klinikai orvoslásban az egyik leggyakoribb tünet és panasz. A sürgősségi ellátás során a vizsgáló elsődleges feladata, hogy a szédülés hátterében kiszúrje azokat az okokat, melyek esetén az osztályos felvétel vagy az akut beavatkozás elmaradása fatális következményekkel járna² ${ }^{2}$ Bár az ágy melletti diagnosztika napjainkban reneszánszát éli, a szédülésdiagnosztika még mindig nehéz feladat, és számos hibalehetőséget rejt magában $^{3}$. Ez nem csak Magyarországon van így, a téves diagnózisok aránya a külföldi irodalomban $74 \%$ és $81 \%$ közé tehetô ${ }^{4,5}$.

A szédüléses kórképek etiológiai háttér szempontjából két fó csoportja a centrális, valamint a perifériás laesio, aminek differenciáldiagnózisa a terápiás döntés, illetve annak sürgőssége szempontjából kritikus. Az eddigi tapasztalatok alapján a szédülés háttere körülbelül 42,6\%-ban valamilyen perifériás, belsőfül eredetû eltérés ${ }^{6}$. A perifériás eltérések leggyakoribb oka a benignus paroxysmalis pozicionális vertigo $(\mathrm{BPPV})^{7}$, emellett lényeges szempont a neuronitis vestibularis ${ }^{8}$ és a Menièrebetegség (MD) ${ }^{9}$ differenciáldiagnózisa is. A centrális, alapvetően központi idegrendszeri eredetú szédülésnek számtalan oka lehet, a legfontosabbak közül megemlítve például cerebrovascularis eltérések, sclerosis multiplex, migrén, neurodegeneratív eltérések és toxikus hatások állhatnak a háttérben ${ }^{10}$.

Varga és munkatársai 2014-es közleményükben megállapították, hogy a Sürgősségi Osztályon ellátott betegeik többségét, $81 \%$-át 24 órán belül otthonukba bocsátották, a többi $19 \%$ döntő többségében fül-orr-gégészeti, illetve ideggyógyászati osztályra került. Az ambulánsan távozó betegek végső diag- nózisát vizsgálva az összes szédülés 57\%-ában nem született specifikus diagnózis, ők a „szédülékenység" tüneti diagnózisát kapták. A további 43\%-ban a diagnózis tükrözte a szédülés hátterében álló feltételezett betegséget. Megállapításaik szerint a szédülés, ijesztố volta ellenére ritkán jelez életveszélyes betegséget, és a koponya-CT-vizsgálat adataik szerint 96\%-ban irreleváns volt. Véleményünk szerint az ágy melletti vizsgálatok sokkal nagyobb jelentőséggel bírnak, amit más munkacsoport elemzése is alátámaszt ${ }^{3}$.

Jelen tanulmány célja az volt, hogy felmérjük, mi történt a továbbiakban a sürgôsségi osztályról elbocsátott szédülős betegekkel. Elemzéseinkben kiemelt helyen szerepel annak vizsgálata, hogy milyen arányban történt meg a fül-orr-gégészeti és egyensúlyrendszeri (otoneurológiai) kivizsgálás a sürgősségi osztályon felállított diagnózis alapján indokolt esetekben.

\section{Módszerek}

Retrospektív, kérdőíves felméréssel készült tanulmányunk célja a sürgôsségi osztályról elbocsátott betegek utánkövetése volt. Intézményünk sürgôsségi osztályán szédülés, szédülékenység (BNO: H81, R42H0) miatt 2017-ben, 2018-ban és 2019 elsô félévében 879 beteg jelent meg, akiknek kérdőívet küldtünk ki (1. ábra). A kérdốívet 308 beteg (110 férfi, 198 nô, átlagéletkor $61,8 \pm 12,31$ SD) juttatta vissza (35\%). A nem válaszolók között a nóbetegek aránya $64 \%$, az átlagéletkor 58,76 $\pm 4,31$ SD volt; a statisztikai elemzés alapján a kérdőívet kitöltók életkorával összevetve nem volt szignifikáns különbség $(\mathrm{p}=0,15)$, ennek alapján a vizsgált minta a populációra nézve reprezentatívnak tekinthető. A nem válaszolók között a diagnózisok megoszlása a következőképpen alakult: szédülékenység $(24,71 \%)$, központi eredetû szédülés $(28,12 \%)$, BPPV $(19,64 \%)$, 
egyéb perifériás eredetű szédülés $(12,05 \%)$, neuronitis vestibularis $(5,89 \%)$, migrén $(1,49 \%)$ és MD $(2,55 \%)$. Az adatok elemzését az intézményi kutatásetikai bizottság engedélyezte (Semmelweis Egyetem, Regionális Intézményi Tudományos és Kutatásetikai bizottság; 28/2018).

A kérdőív elsố részében rákérdeztünk a szédülést kísérő különböző panaszokra, illetve arra, hogy milyen diagnózisról tájékoztatták a beteget a sürgősségi osztályon, illetve hogy a későbbi kivizsgálás során (ami adott esetben jelentheti kizárólag a háziorvosi vizitet is) milyen diagnózis igazolódott, majd ezeket összevetettük.

A kérdőív második részeként DHI-t (dizziness handicap inventory) küldtünk ki; a DHI 25 standardizált kérdést tartalmaz a szédülés életminőséget befolyásoló hatásáról (tüneti, funkcionális, valamint emocionális score-rendszerek). A maximálisan elérhetô pontszám 100, az életminőség-romlás kategóriái pedig a következók: enyhe (16-34), közepes (36-52) és súlyos $(54 \leq)$. A kérdőív ugyan magyar nyelven még nem validált, számos országban a validálása megtörtént, és magunk is több alkalommal ${ }^{11}$ használtuk szédülő betegek állapotának utánkövetésében ${ }^{12,13}$.

A statisztikai elemzéseket IBM SPSS V24 szoftver segítségével hajtottuk végre. Mivel a paraméterek nem mutattak normáleloszlást, nem parametrikus teszteket alkalmaztunk (Mann-Whitney Uteszt, Cohen-féle Kappa-teszt), és minden esetben a $\mathrm{p}<0,05$ értéket tekintettünk szignifikánsnak.

A kitöltött kérdőívek alapján elsősorban arra kerestünk választ, hogy a sürgősségi osztályról történô távozás után mi történt a szédülést panaszoló beteggel, ennek kapcsán azt is vizsgáltuk, hogy milyen szakorvosi vizsgálatok történtek meg, illetve hogy az ezek során felállított végsô diagnózis mennyire esett egybe a sürgősségi osztályon megállapítottakkal. Vizsgáltuk azt is, hogy a végleges diagnózis felállításáig átlagosan mennyi idő telt el, és ez mennyiben befolyásolja a betegek életminőségét.

\section{Eredmények}

A Sürgősségi Osztály zárójelentésein szereplő diagnózisok megoszlását az 1. táblázat mutatja.

Ahogy az 1. táblázaton látható, a perifériás diagnózisok között az első helyen áll a BPPV $(16,56 \%)$, leggyakoribb diagnózisként viszont a központi eredetû szédülés $(23,05 \%)$ és a szédülékenység $(20,78 \%)$ szerepel. Kiemelendő, hogy konkrét diagnózis az esetek 24,02\%-ában nem született, ami nem azt jelenti, hogy nem releváns diagnózis született, hanem hogy a beteget ténylegesen

\section{Akut szédüléses betegek utánkövetése kérdöív}

Az ön TAJ száma:

Néhány kérdést tennénk fel a szédülésével kapcsolatban. Kérjük, jelölje (karikázza be, vagy húzza alá) be a leginkább megfelelö választ!

\begin{tabular}{|c|c|c|c|}
\hline $\begin{array}{l}\text { A szédülés forgó } \\
\text { jellegü volt-e? }\end{array}$ & Igen & Nem & Nem emlékszem \\
\hline Mennyi ideig tartott? & \multicolumn{3}{|c|}{$\begin{array}{c}\text { másodpercek, percek, órák, egy nap, több nap, azóta is tart, nem } \\
\text { emlékszem }\end{array}$} \\
\hline Volt-e hányingere? & Igen & Nem & Nem emlékszem \\
\hline Volt-e hányás? & Igen & Nem & Nem emlékszem \\
\hline Volt-e hallásromlás? & Igen & Nem & Nem emlékszem \\
\hline Volt-e fülzúgás? & Igen & Nem & Nem emlékszem \\
\hline Volt-e látászavar? & Igen & Nem & Nem emlékszem \\
\hline $\begin{array}{l}\text { Volt-e } \\
\text { eszméletvesztés? }\end{array}$ & Igen & Nem & Nem emlékszem \\
\hline Volt-e fejfájása? & Igen & Nem & Nem emlékszem \\
\hline
\end{tabular}

Amikor hazaengedték a sürgősségi osztályról, mit mondtak Önnek, mi okozta a szédülését? (Kérjük, hogy saját szavaival röviden irja le!)

A következö kérdések arra vonatkoznak, hogy mi történt Önnel, miután hazament a sürgősségi osztályról!

\begin{tabular}{|l|l|l|}
\hline Felkereste a háziorvosát? & igen & nem \\
\hline $\begin{array}{l}\text { Felkereste a fül-orr-gégészeti } \\
\text { szakrendelöt? }\end{array}$ & igen & nem \\
\hline $\begin{array}{l}\text { Felkereste a neurológiai } \\
\text { szakrendelöt? }\end{array}$ & igen & nem \\
\hline Belgyógyászhoz fordult? & igen & nem \\
\hline $\begin{array}{l}\text { Egyéb szakorvoshoz fordult? } \\
\text { (Ha igen, írja le, milyen } \\
\text { szakorvos volt!) }\end{array}$ & igen, éspedig: & nem \\
\hline $\begin{array}{l}\text { Küldték-e Önt } \\
\text { egyensúlyrendszeri } \\
\text { (otoneurológiai) vizsgálatra? }\end{array}$ & igen & nem \\
\hline
\end{tabular}

Kérjük, saját szavaival röviden írja le, hogy mit állapított meg az orvos a vizsgálatok befejeződése után!

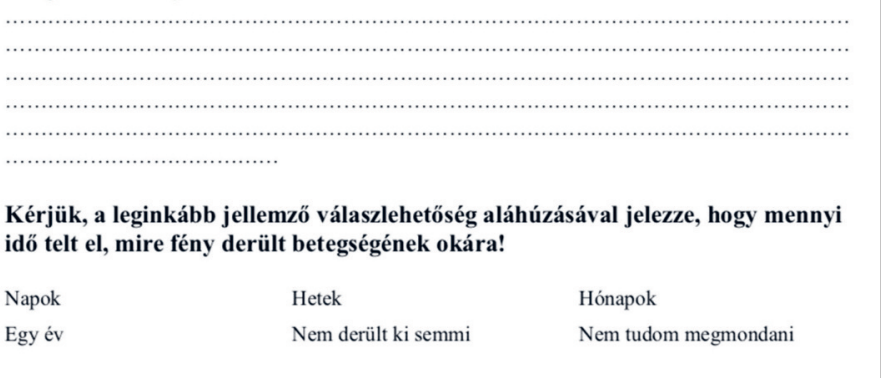

1. ábra. A betegekhez eljuttatott kérdő́iv

nem tájékoztatták betegségének lehetséges okáról. A súlyos életveszélyes betegségeket az esetek többségében sikerült kiszûrni, a betegek 14,83\%-án igazolódott TIA (tranziens ischaemiás attak)/akut stroke, a diagnosztikus hiba pedig 9\%-nak adódott; ezen eredmények megfelelnek a nemzetközi irodalomban olvasottaknak ${ }^{14}$. Esetükben az akut kezelés hatékonysága 37\%-nak adódott. Az így felállított diagnózisok, valamint a későbbi szakvizsgálatok eredményét igyekeztünk összevetni, ezért rákérdez- 
1. táblázat. A sürgốsségi osztályon felállitott diagnózisok megoszlása

\begin{tabular}{|lll|}
\hline BNO kódok & Betegség & Betegszám \\
\hline Nincs & & \\
diagnózis & & $74(24,02 \%)$ \\
H8140 & Központi eredetú szédülés & $71(23,05 \%)$ \\
R42H0 & Szédülékenység & $64(20,78 \%)$ \\
H8110 & BPPV & $51(16,56 \%)$ \\
H8130 & Egyéb perifériás eredetú szédülés & $32(10,39 \%)$ \\
H8120 & Neuronitis vestibularis & $10(3,25 \%)$ \\
H8100 & MD & $4(1,3 \%)$ \\
G4310 & Migrén & $2(0,65 \%)$ \\
& & \\
\hline
\end{tabular}

2. táblázat. A sürgösségi osztályról történt távozás után felkeresett szakellátók (a beteg elmondása alapján)

\begin{tabular}{|ll|}
\hline Szakterület & Betegszám \\
\hline Háziorvos & 128 \\
Neurológia & 81 \\
Belgyógyászat & 72 \\
Fül-orr-gégészet & 67 \\
Otoneurológiai vizsgálat & 14 \\
Kardiológia & 8 \\
Szemészet & 5 \\
Pszichiátria & 4 \\
Reumatológia & 4 \\
Neuroradiológia (MR) & 4 \\
Immunológia & 2 \\
Gyógytornász & 2 \\
Angiológia & 1 \\
Egyéb & 16 \\
\hline
\end{tabular}

tünk, hogy a Sürgősségi Osztály elhagyása után milyen szakvizsgálatok történtek (2. táblázat).

A 2. táblázat alapján látható, hogy a szédülést panaszoló betegek leggyakrabban a háziorvost keresték fel, ezt követi a sorban a neurológiai, a fülorr-gégészeti, valamint a belgyógyászati kivizsgálás. Összehasonlítva a későbbi kivizsgálások, valamint a sürgősségi kivizsgálás eredményét (a sürgősségi felvételt végzô orvos dokumentációja alapján) egyezés csupán 44 beteg $(14,3 \%)$ esetében volt megfigyelhető; az esetek döntő többségében az egyező diagnózis BPPV volt.
A statisztikai elemzés érdekében a diagnózisokat két nagy csoportra osztottuk: vestibularis és extravestibularis eltérések. A statisztikai értékeléshez a Cohen-féle Kappa-tesztet alkalmaztuk. Vestibularis eltérésnek tekintettük az MD-t, a neuronitis vestibularist, a BPPV-t és az egyéb vestibulopathiákat. Extravestibularis eltérések: centrális vestibularis múködészavar, belgyógyászati eredetú, a nyaki gerinc deformitásaihoz társuló, illetve pszichogén eredetú szédülések, valamint szédülékenység. A vizsgált populációban a szédülés 244 betegnél $(79,2 \%)$ jelentkezett vezető tünetként, és 64 beteg $(20,8 \%)$ esetében volt valamilyen belgyógyászati betegség (ritmuszavar, infarktus, hypertonia, carotisatherosclerosis) kísérőtünete.

Az elemzés érdekében vestibularis/extravestibularis csoportokra osztottuk a diagnózisokat. A teszt eredménye alapján $\kappa=0,560$, ami a teszt interpretálásának megfelelően moderált összefüggésnek minősül (moderált: 0,41-0,60).

Ahogy a 3. táblázat alapján látható, még ha leegyszerúsítve, nagyobb diagnosztikai gyújtőcsoportok alapján hasonlítjuk is össze a diagnózisokat, a korreláció akkor is csak moderált, nem túl kifejezett.

Elemzéseink kiemelten fontos része volt a DHIkérdőívek elemzése, hiszen ennek eredménye a betegek életminőségérôl ad információt. Három csoport között vetettük össze az össz-DHI-értékeket, az alapján, hogy a végső diagnózisig mennyi idő telt el (napok, hetek, hónapok vagy egy év). A végleges diagnózis tisztázásáig leggyakrabban napok $(28,8 \%)$, illetve hetek $(24,2 \%)$ teltek el, kiemelendő azonban, hogy az esetek 24,02\%-ában végleges diagnózis sosem született.

A betegeket két csoportra osztva (diagnózis született/nem született) összehasonlítottuk, hogyan alakult a betegek életminősége a két csoportban. Mann-Whitney U-teszt alapján szignifikáns különbség $(\mathrm{p}=0,044)$ adódott a két csoport össz-DHIértékei között, rámutatva, hogy diagnózis és adekvát kezelés hiányában a betegek életminősége jelentősen romlik.

Ahogy a 2. ábrán látható, a legtöbb esetben a diagnózis felállításáig eltelt idővel arányosan növekszik az életminőség-romlás értéke, erre utalnak

3. táblázat. Cohen-féle Kappa-teszt a sürgösségi diagnózis és a késóbb felállitott diagnózis közötti összefüggés vizsgálatára

\begin{tabular}{|lll|}
\hline & $\begin{array}{l}\text { Sürgősségi diagnózis alapián } \\
\text { vestibularis }\end{array}$ & $\begin{array}{l}\text { Sürgősségi diagnózis alapián } \\
\text { extravestibularis }\end{array}$ \\
\hline Későbbi kivizsgálás alapián vestibularis & 122 & 13 \\
Későbbi kivizsgálás alapián extravestibularis & 56 & 117 \\
\hline
\end{tabular}


az egyes csoportokban meghatározott átlagértékek és a p-értékek.

\section{Megbeszélés}

A kérdőívet minden, a vizsgált idôszakban sürgôsségi osztályon szédülés miatt kezelt betegnek kiküldtük. A visszaküldött kérdőívek küldői között minden korosztály előfordult, ugyanakkor az átlagéletkor alapján a 40 év felettiek jelentek meg nagyobb arányban, ami megfelel a mindennapi gyakorlatnak. A kérdőívet visszaküldők között nagyobb volt a nők aránya, ami szintén a klinikai gyakorlatnak megfelelő. A többi paraméter tekintetében a válaszolók és nem válaszolók aránya nem különbözött lényegesen, így a minta reprezentatívnak tekinthető. A visszajuttatott kérdőívek aránya a szédülő betegek együttmúködési készségét is jól prezentáló tényezô. Fontos hangsúlyozni azonban, hogy a szédülés okának felderítése még szakképzett személy számára is nehéz feladat, ezért a kérdőívek használata számos limitációt rejt magában. A szédülés diagnosztikájában és főleg terápiájában kiemelten fontos lenne a betegek hosszú távú együttmúködése.

A sürgősségi zárójelentésre írt diagnózisok és a betegeknek mondott szóbeli tájékoztatás összevetésében még több az ellentmondás. Nagyon sok beteg egyáltalán nem kapott tájékoztatást, és számos beteg nem arról a betegségrôl kapott magyarázatot, ami a zárójelentésében szerepelt. A mai számítógépes világban a beteg távozása után azonnal tájékozódik az internetről, és ha a leírt és szóban elmondott diagnózis között ellentmondás van, az teljesen összezavarja. Ennek következtében a beteg elégedetlenné válik, és a tisztázatlan diagnózis fokozza a - szédülő betegekre egyébként is jellemző - szorongást ${ }^{15}$. Különösen igaz ez akkor, ha a diagnózisok között a stroke is szerepel.

A beteg szorongását fokozza, ha a sürgósségi osztályról történt távozása és a kivizsgálási folyamat vége között túl sok idô telik el, erre utal a DHIértékek változásában megfigyelhetô tendencia és a romló életminőség. Az egyes vizsgálatok hazánkban manapság időpont-egyeztetést követően zajlanak, és a betegek negyedében ez az időpont több hónappal később is lehetett. A betegek negyede esetében a vizsgálatok lezajlása után nem derült ki a végleges diagnózis. Ennek oka lehet az, hogy az anamnézis lényeges szempontjai az idő elteltével feledésbe merülnek, vagy az addig megszerzett vizsgálati eredmények tükrében módosulnak, miközben a beteg állapota folyamatosan változik, javul vagy romlik. Miközben organikus státusza javulhat, pszi-

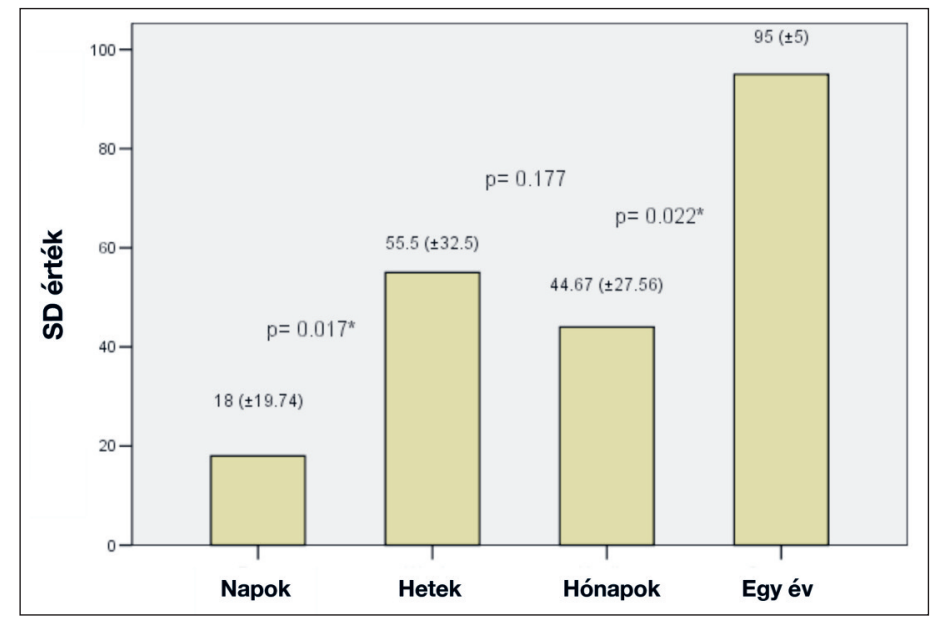

2. ábra. Össz-DHI - diagnózisig eltelt idő

chés státusza rosszabbodhat, újabb és újabb tünetek kerülhetnek előtérbe, amiknek korábban nem tulajdonított jelentőséget. Korábbi közleményben (Varga és munkatársai) 57\%-ban nem született végleges diagnózis, az arány tehát valamelyest javuló tendenciát mutat ${ }^{2}$. A sürgősségi osztály diagnózisa és a végleges diagnózis csak a betegek negyedében esett egybe. Ez nagyon alacsony diagnosztikus aránynak túnik, de a téves diagnózisok aránya a nemzetközi irodalomban is hasonló ${ }^{16}$. Indokolt lenne az otoneurológiai vizsgálat a perifériás vestibularis szédülés jellegének tisztázására, és a végleges diagnózis megállapítására.

A betegek közül csak 14 jutott el otoneurológiai vizsgálatra, és fül-orr-gégészeti szakvizsgálat is csupán 67 beteg esetében történt. Bár a vestibularis rendszer célzott vizsgálata a többi vizsgálattal együtt segítséget nyújthat az egyensúlyzavarok okának tisztázásában, a sürgősségi osztályon végzett célzott, ágy melletti egyensúlyvizsgálatot nem pótolja. Különösen igaz ez azokra az eltérésekre, amelyek az akut szakasz lezajlását követően nem a tipikus tüneteket mutatják (például BPPV, neuronitis), így a későbbi szakvizsgálat során a sürgősségi dokumentációból nyert értékes adatok (például korábbi pozitív Dix-Hallpike-manőver) alapján van lehetóség ,retrospektíve” igazolni a diagnózist.

A szédüléssel jelentkező betegek sürgősségi diagnosztikája nagy kihívás a sürgősségi osztály dolgozói számára. Döntően határterületi kérdésről van szó, és a beteg - rosszulléte miatt - nem is mindig alkalmas minden vizsgálat elvégzésére. A pontos anamnézis és a gyors, célzott vizsgálat az esetek többségében mégis tisztázhatja az alapvetô kérdéseket. Hangsúlyozni szeretnénk, hogy a pontos diagnózis felállítása nem a sürgősségi ellátás feladata, ennek helye a későbbi szakorvosi kivizsgálás, az 
4. táblázat. A HINTS+ (head-impulse test, nystagmus, test of skew deviation, +: halláscsökkenés)

\begin{tabular}{|c|c|c|c|c|c|c|c|}
\hline HINTS+ & Nystagmus & & HIT & & $\begin{array}{l}\text { Skew } \\
\text { deviáció }\end{array}$ & & $\begin{array}{l}\text { Akut } \\
\text { halláscsökkenés }\end{array}$ \\
\hline $\begin{array}{l}\text { Perifériás } \\
\text { Centrális }\end{array}$ & $\begin{array}{l}\text { spontán } \\
\text { tekintésiránvú }\end{array}$ & $\begin{array}{l}+ \\
\text { és/vgay }\end{array}$ & lassú fázis irányába pozitív & $\begin{array}{l}+ \\
\text { és/vagy }\end{array}$ & nincs & $\begin{array}{l}+ \\
\text { és/vagy }\end{array}$ & nincs \\
\hline
\end{tabular}

HIT: fej-impulzusteszt (head impulse test)

AVS (akut vestibularis szindróma) azonban azonnali diagnosztikát igényel, ugyanis a centrális és perifériás esetek elkülönítése elengedhetetlen.

Az AVS fogalmát Hotson és Baloh vezette be 1998-ban ${ }^{17}$. AVS-ról beszélünk, ha a betegnek olyan szédüléses panasza van, ami 24 óránál hoszszabb ideig tart, járászavar, valamint vegetatív tünetek jelennek meg, és spontán nystagmus látható $^{18}$. Izolált AVS-ról beszélünk, ha a neurológiai tünetek hiányoznak, ilyen például az AVS leggyakoribb oka, a neuronitis vestibularis, de jelentkezhet hátsó scala stroke esetén is - ebben az esetben a differenciáldiagnosztika különösen fontos és nehéz feladat. Az irodalom szerint a sürgősségi osztályon megjelenő betegek 10-20\%-ánál látható.

Az AVS második leggyakoribb oka a kisagy vagy az agytörzs területén bekövetkezett ischaemiás stroke ${ }^{19}$. Fontos megjegyezni, hogy a hátsó scala stroke-ban szenvedó betegek leggyakoribb tünete a vertigo és a nystagmus ${ }^{20,21}$. Egy negatív képalkotó vizsgálati eredmény (CT, MR) nem zárja ki a stroke diagnózisát, az egyik legmegbízhatóbb diagnosztikus eljárás a HINTS+ (head-impulse test, nystagmus, test of skew deviation, +: halláscsökkenés). A HINTS+ segítségével (4. táblázat) differenciálható, hogy a szédülés centrális vagy perifériás eredetû-e; amennyiben rohamokban jelentkező perifériás szédülésról van szó, célszerú azt is pontosítani, hogy melyik perifériás betegség állhat a hát-

\section{IRODALOM}

1. Jung I, Kim J-S. Approach to dizziness in the emergency department. Clin Exp Emerg Med 2015;2(2):75-88. https://doi.org/10.15441/ceem.15.026

2. Varga C, Nagy F, Drubits $K$, et al. Analysis of patients applying for emergency treatment with vertigo related symptoms. [A sürgősségi ellátásban szédüléssel jelentkező betegek adatainak elemzése.] Ideggyogy Sz 2014;67:193200. [Hungarian].

3. Tamás TL, Garai T, Tamás Tompos T, et al. Vertigo in the Emergency Department: new bedside tests. [Szédülés vizsgálata a sürgősségi osztályon: új, ágy melletti diagnosztikai eljárások.] Orv Hetil 2016;157:403-9. [Hungarian]. https://doi.org/10.1556/650.2016.30388 térben. Leggyakrabban MD, neuronitis vestibularis, BPPV, vestibularis migrén magyarázhatja a panaszokat.

A sürgősségi dokumentációt áttekintve látható volt, hogy a HINTS+ vizsgálat nem terjedt el a gyakorlatban: általános, hogy a vizsgáló orvos a spontán nystagmust, statokinetikus próbákat (Rombergpróba, Bárány-próba), esetleg a Dix-Hallpikemanővert vizsgálja, a HIT és skew-deviáció vizsgálata azonban nem képezi a mindennapi rutin részét. $\mathrm{Az}$ ágy melletti vizsgálatok helyett az akut koponya-CT elvégzését preferálják, holott a HINTS+ érzékenysége meghaladja a képalkotó vizsgálatokét.

Mindenképpen javasolt a beteget megfelelóen tájékoztatni arról, hogy a szédülését egyensúlyrendszeri érintettség okozhatta, vagy ennek hiányában tájékoztatni az egyéb lehetséges okokról (például belgyógyászati betegség). Tájékoztatni kell arról is, hogy milyen betegségre gyanakszunk, és ezzel milyen szakorvoshoz kell fordulni, esetleg arról is, hogy a betegség visszatérhet, és akkor mi a teendő. Ha ezt tudja, akkor nem elégedetlen és szorongó beteg fog távozni a sürgósségi osztályról, hanem olyan jól informált páciens, aki tudja, hogy milyen betegség gyanúja merült fel, és milyen vizsgálatokra kell majd eljutnia a közeljövőben. Az elégedett betegek hosszú távon csökkenthetik a sürgósségi részleg betegforgalmát is.

4. Kerber KA, Morgenstern LB, Meurer WJ, et al. Nystagmus assessments documented by emergency physicians in acute dizziness presentations: a target for decision support? Acad Emerg Med 2011;18:619-26. https://doi.org/10.1111/j.1553-2712.2011.01093.x

5. Royl G, Ploner CJ, and Leithner C. Dizziness in the emergency room: diagnoses and misdiagnoses. Eur Neurol 2011;66:256-63. https://doi.org/10.1159/000331046

6. Strupp M, Dieterich M, Brandt T. The treatment and natural course of peripheral and central vertigo. Dtsch Arztebl Int 2013;110(29-30):505-16.

7. Maihoub S, Molnár A, Fent Z, Tamás L, Szirmai Á. Objective diagnostic possibility in the differentiation of idiopa- 
thic and secondary benign paroxysmal positional vertigo. Orv Hetil 2020;161(6):208-13. https://doi.org/10.1556/650.2020.31646

8. Seong-Hae Jeong, Hyo-Jung Kim, Ji-Soo Kim. Vestibular Neuritis. Semin Neurol 2013;33:185-94. https://doi.org/10.1055/s-0033-1354598

9. Molnár A, Maihoub S, Tamás L, Szirmai Á. Intratympanically administered steroid for progressive sensorineural hearing loss in Ménière's disease. Acta Oto-Laryngologica 2019;139(11):982-6. https://doi.org/10.1080/00016489.2019.1658898

10. Karatas $M$. Central vertigo and dizziness: Epidemiology, differential diagnosis, and common causes. The Neurologist 2008;14(6):355-64. https://doi.org/10.1097/nrl.0b013e31817533a3

11. Szirmai Á, Maihoub S, Molnár A, Fent Z, Tamás L, Polony $G$. Effect of the stapedius and tensor tympani muscles tenotomy on the quality of life of patients suffering from Ménière's disease. Orv Hetil 2020;161(5):177-82. https://doi.org/10.1556/650.2020.31634

12. Szirmai Á, Maihoub S, Tamás L. Efficacy of assisted balance training in chronic vestibular vertigo. [Asszisztált egyensúlyi tréning hatékonysága krónikus vestibularis rendszeri szédülésben.] Orv Hetil 2018;159:470-7. [Hungarian] https://doi.org/10.1556/650.2018.31012

13. Nola G, Mostardini C, Salvi AP, Ralli EG. Validity of Italian adaptation of the Dizziness Handicap Inventory (DHI) and evaluation of the quality of life in patients with acute dizziness. ACTA Otorhinolaryngologica Italica 2010;30: 190-7.
14. Morgenstern LB, Lisabeth LD, Mecozzi AC, Smith MA, Longwell PJ, McFarling DA, et al. A population-based study of acute stroke and TIA diagnosis. Neurology Mar 2004;62(6):895-900. https://doi.org/10.1212/01.wnl.0000115103.49326.5e

15. Fazekas A. Szédülés - Komorbiditás pszichiátriai betegsekkel. [Vertigo - Comorbidity with psychiatric disordes]. Ideggyogy Sz 2010;63(3-4):113-7.

16. Edlow JA. Diagnosing patients with acute-onset persistent dizziness. Ann Emerg Med 2018;71:625-31. https://doi.org/10.1016/j.annemergmed.2017.10.012

17. Hotson JR, Baloh $R W$. Acute vestibular syndrome. N Engl J Med 1998;339:680-5. https://doi.org/10.1056/nejm199809033391007

18. Tarnutzer AA, Berkowitz AL, Robinson KA, et al. Does my dizzy patient have a stroke? A systematic review of bedside diagnosis in acute vestibular syndrome. CMAJ 2011;183:E571-92. https://doi.org/10.1503/cmaj.100174

19. Newman-Toker DE. Missed stroke in acute vertigo and dizziness: It is time for action, not debate. Ann Neurol 2016;79. https://doi.org/10.1002/ana.24532

20. Caplan LR, Wityk RJ, Glass TA, et al. New England medical center posterior circulation registry. Ann Neurol 2004; 56:389-98.

21. Searls DE, Pazdera L, Korbel E, et al. Symptoms and signs of posterior circulation ischemia in the new England medical center posterior circulation registry. Arch Neurol 2012; 69:346-51.

https://doi.org/10.1001/archneurol.2011.2083 